\title{
SOCIO-ECONOMIC HEALTH DIFFERENCES IN THE NETHERLANDS: A REVIEW OF RECENT EMPIRICAL FINDINGS
}

\author{
J. P. MaCkenbach \\ Department of Public Health and Social Medicine, Erasmus University Medical School, P.O. Box 1738, \\ 3000 DR Rotterdam, The Netherlands
}

\begin{abstract}
Evidence on variation in the frequency of health problems between socio-economic groups in the Dutch population has accumulated rapidly in recent years. This paper presents a review of these recent data.

It is clear now that a lower socio-economic status is associated with a higher frequency of a wide range of health problems. This negative association has consistently been found for the following health indicators: birth weight; adult body height; prevalence of health complaints; prevalence of many chronic conditions; prevalence of disability; incidence of long-term work incapacity; perceived general health; adult mortality. Inconsistent findings were reported for: children's body height; prevalence of some chronic conditions; incidence of sickness absence (short-term work incapacity); perinatal mortality.

The magnitude of the differences varies from study to study, and possibly from health problem to health problem. In studies categorizing the study population in 3-6 hierarchically ordered socio-economic groups on the basis of either education or occupational status, the Relative Risks (of the lowest versus the highest socio-economic group) mostly lie between $I$ and 2 . Exceptions are prevalence of disability and incidence of long-term work incapacity where Relative Risks between 2 and 4 have been found. A direct comparison with data from other countries is problematic, but at first sight the differences as observed in the Netherlands seem to be of the same order of magnitude as those observed in other industrialized countries. Although most Relative Risks imply 'weak associations' from a technical-epidemiological point of view, the Population Attributable Risks are substantial (generally between 0.25 and 0.40 ), underlining the public health impact of socio-economic health differences.

Information on trends in health inequalities over time is limited to children's body height and adult mortality. For children's body height a substantial decrease of inequalities was found between 1964-1966 and 1980. For adult mortality, on the other hand, there is (indirect) evidence of a widening of the mortality gap between the 1950 s and the 1980s.

The evidence on specific factors which are involved in the 'causal chain' between socio-economic status and health problems is rather limited at the moment. A negative association with socio-economic status has been reported for the following risk factors: smoking; obesity; a number of unfavourable material living conditions; a number of unfavourable physical working conditions; psychosocial stress; lack of social support; less adequate supply/use of health care. On the other hand, study results have not shown a higher prevalence in the lower socio-economic groups for: high alcohol consumption; high blood pressure; high serum cholesterol. Some unfavourable food habits (e.g. a high fat intake) are more common in lower socio-economic groups, but others are not (e.g. high intake of poly-unsaturated fatty acids).

The paper ends with a number of recommendations for further descriptive and explanatory studies.
\end{abstract}

Key words-inequalities in health, socio-economic status, mortality, morbidity, risk factors, the Netherlands

\section{INTRODUCTION}

Evidence on differences in the frequency of health problems between socio-economic groups in the Dutch population has accumulated rapidly in recent years. The yearly number of publications in which new empirical findings on socio-economic health differences (SEHD) are presented is quite substantial: between 30 and 40 in each of the years 1987,.1988 and 1989 . The body of knowledge grows so rapidly that three other recently published reviews of the Dutch situation, based on studies published through 1986 and 1987 respectively, already are more or less outdated [1-3].

The rise in the number of publications partly reflects the response of Dutch researchers to the increasing awareness of SEHD among health policy makers. Following the international upsurge in the attention paid to SEHD, promoted by the publication of the Black Report [4] and the inclusion of a reduction of health inequalities among the World Health Organization's targets for the year 2000 [5], the Dutch Ministry of Welfare, Public Health and Culture included a paragraph on SEHD in a major policy document [6]. After a conference in 1987 [7] and the commissioning of a number of small-scale studies in 1988, this commitment made the Ministry launch a research programme for the years 1989-1993 [8].

In this paper a review will be given of recent empirical findings on SEHD in the Netherlands. This review is divided into three parts. 
-In a first part, an account will be given of studies quantifying the extent of socio-economic differences in the occurrence of various health problems in the Dutch population. The following categories will be distinguished: anthropometric characteristics (birth weight, body height); health complaints; morbidity; disability; perceived general health; mortality.

-In a second part, we will review some recent evidence concerning the explanation of SEHD in the Netherlands. This evidence is mainly restricted to studies quantifying the extent of socio-economic differences in the prevalence of various specific risk factors, but also derives from a few studies analysing the interrelationships between socio-economic status, specific risk factors and health.

-Finally, we will summarize the Dutch situation against the background of the situation in a number of other countries, and give some suggestions for further research.

This review does not include studies of psychiatric or dental problems. Where available we will also present data showing the evolution of SEHD over time.

\section{SOCIO-ECONOMIC DIFFERENCES IN THE OCCURRENCE OF VARIOUS HEALTH PROBLEMS}

Over the last few years the Netherlands Health Interview Survey of the Central Bureau of Statistics has become the single most important source of information on SEHD in the Netherlands [9]. A summary of the most salient findings, which concern a wide range of health problems, is presented in
Table 1. Summaries for other health problems are presented in Tables 2 (children's body height), 3 (specific chronic conditions) and 4 (adult mortality).

\section{Anthropometric characteristics}

SEHD start before birth: birth weight, which is a powerful predictor of the occurrence of health problems of the fetus and the new-born, is lower in babies of parents with a lower educational level and/or lower net income (Table 1). The differences are substantial: more than $200 \mathrm{~g}$ difference between mothers with primary school only and mothers with vocational college or university [10]. Data on the distribution of birth weights by socio-economic group are not available, but the differences in average birth weight suggest that the proportion of low birth weight babies is higher in lower socio-economic groups. Birth length is only weakly associated with parents' socio-economic status, and the differences are quite small [10].

In a study of a national sample of 42,000 healthy children in 1980 it was found that for young children differences in measured body height between socioeconomic groups (according to father's occupational status) were small and inconsistent. Above the age of 4 , however, children of fathers of higher occupational status were clearly longer (Table 2) [15]. Differences in children's height (all ages) by socio-economic status have also been found in several other studies, including an analysis of data on the height of 5700 children (as reported by their parents) from the Netherlands Health Interview Survey of 1981 and 1982 [16]. There have, however, also been some reports of a lack of association between children's

Table 1. Socio-economic health differences according to the Netherlands Health Interview Survey

\begin{tabular}{|c|c|c|c|c|c|c|c|c|c|c|c|}
\hline & \multicolumn{5}{|c|}{ Level of education" } & \multicolumn{6}{|c|}{ Net household income ${ }^{b}$} \\
\hline & 1 & 2 & 3 & 4 & 5 & 1 & 2 & 3 & 4 & 5 & 6 \\
\hline $\begin{array}{l}\text { Average birth weight } \\
\quad(1981-1985 ; \text { in } \mathrm{g}[10]) \\
\text { Averaged adult height } \\
\quad(1981-1983 ; \text { in } \mathrm{cm}[11])\end{array}$ & 3190 & 3338 & 3341 & & & 32 & & 3376 & 3311 & & \\
\hline $\begin{array}{l}\text {-men } \\
\text {-women }\end{array}$ & $\begin{array}{l}175.1 \\
165.4\end{array}$ & $\begin{array}{l}176.5 \\
166.0\end{array}$ & $\begin{array}{l}178.0 \\
166.4\end{array}$ & $\begin{array}{l}179.0 \\
167.5\end{array}$ & $\begin{array}{l}180.0 \\
167.7\end{array}$ & - & - & - & - & $\overline{-}$ & - \\
\hline $\begin{array}{l}\text { Health complaints }^{d} \\
\text { (1983-1985: } \\
\text { VOEG-score, } 48 \text { items [9]) }\end{array}$ & 8.4 & 6.9 & 6.1 & 5.2 & 5.2 & 8.4 & $\overline{8.1}$ & $\overline{7.1}$ & $\overline{6.4}$ & $\overline{6.1}$ & $\overline{5.5}$ \\
\hline $\begin{array}{l}\text { Chronic conditions }{ }^{\AA} \\
\text { (1983-1985; } \\
\text { number per } 100 \text { persons [9]) }\end{array}$ & 46 & 41 & 39 & 35 & 29 & 48 & 47 & 44 & 39 & 38 & 36 \\
\hline $\begin{array}{l}\text { Absence from work } \\
(1981-1984 ; \\
\% \text { persons, in } 1 \text { year [12]) }\end{array}$ & 54.4 & 50.6 & 53.0 & 54.6 & 54.2 & 49.4 & 53.9 & 56.7 & 56.6 & 56.6 & 53.3 \\
\hline $\begin{array}{l}\text { (Very) severe disability } \\
\text { (1986-1988; } \\
\% \text { persons }[13])\end{array}$ & 19.4 & 12.6 & 11.0 & 8.8 & 6.3 & 17.4 & 16.7 & 12.5 & 10.2 & 9.3 & 7.3 \\
\hline $\begin{array}{l}\text { Perceived general health" } \\
\text { (1983-1985; } \\
\% \text { persons "not so good" [9]) }\end{array}$ & 29.0 & .20 .1 & 16.7 & 12.7 & 13.2 & 28.2 & 27.1 & 22.2 & 18.6 & 15.9 & 13.3 \\
\hline \multicolumn{12}{|c|}{$\begin{array}{l}\text { - not investigated or not reported. } \\
\quad 1=\text { primary school }(27 \%) .2=\text { junior (vocational) training }(32 \%) .3=\text { secondary (vocational) education }(30 \%) .4=\text { vocational colleges } \\
\quad(9 \%) .5=\text { university }(3 \%) \text {. } \\
\text { b } 1=<18,000 \text { gld. }(14 \%) .2=18,000-22,000 \text { gld. }(12 \%) .3=22,000-28,000 \text { gld. }(17 \%) .4=28,000-36,000 \text { gld. }(15 \%) .5=36,000-45,000 \text { gld } \\
\quad(11 \%) .6=\geqslant 45,000 \text { gld. }(11 \%) \text {. Unknown }(19 \%) . \\
\text { cAccording to level of education of mother. } \\
\text { dStandardized for age and sex. }\end{array}$} \\
\hline
\end{tabular}


Table 2. Socio-economic differences in body height of children. 1964-1966 and 1980

\begin{tabular}{|c|c|c|c|c|}
\hline \multirow{3}{*}{$\begin{array}{l}\text { Age } \\
\text { (yrs) }\end{array}$} & \multicolumn{4}{|c|}{$\begin{array}{c}\text { Difference (in } \mathrm{mm} \text { ) between average body } \\
\text { height of children in high and } \\
\text { low occupational classes" }\end{array}$} \\
\hline & \multicolumn{2}{|c|}{ Boys } & \multicolumn{2}{|c|}{ Girls } \\
\hline & $1964-1966^{\circ}$ & $1980^{\circ}$ & $1964-1966^{b}$ & $1980^{\circ}$ \\
\hline 0 & n.a. & 2 & n.a. & 1 \\
\hline $1-3$ & 6 & -0 & 4 & $i$ \\
\hline $4-5$ & 22 & 10 & 12 & 4 \\
\hline $6-10$ & 22 & 7 & 22 & 13 \\
\hline $11-16$ & 29 & 14 & 30 & 20 \\
\hline $17-19$ & 21 & 12 & 27 & 17 \\
\hline
\end{tabular}

n.a. Not available.

"Children classified according to occupational status of father. In each study, 3 categories were distinguished: high, middle and low. The 'high'-category contained ca $5 \%$ of children in 1964-1966 and $\mathrm{ca} 8 \%$ in 1980. The 'low'-category contained ca $60 \%$ of children in $1964-1966$ and ca $50 \%$ in 1980 .

${ }^{b}$ Nation-wide, representative sample of approx 55,000 children; differences calculated from detailed data published in Ref. [14]

'Nation-wide, representative sample of approx 42,000 children; differences calculated from detailed data published in Ref. [15].

height and parents' socio-economic status [17-19]. These seemingly discrepant findings are possibly due to aspects of the study design, such as a small sample size or a lack of socio-economic contrast in the study population, but may also indicate that socio-economic differences in children's height are not as large and consistent as they used to be. The latter supposition is confirmed by a comparison between the results of the 1980 national survey and those of a comparable survey held in 1964-1966 [14] (Table 2). Within this 15-year period differences in children's body height by father's occupational status have dramatically declined.

Whatever the situation in younger cohorts may be, there is still a clear association between adult height and socio-economic status: men and women of higher educational level are taller (Table 1). Differences are substantial in men: almost $5 \mathrm{~cm}$ difference between men with primary school only and men with a university education. In women differences are much smaller [11]. Differences in adult body height between socio-economic groups have also been found among 18-year-old boys who are screened for compulsory military service [20].

\section{Health complaints}

The average number of reported health complaints is smaller in higher socio-economic groups. This has

Table 3. Association between socio-economic status and reported chronic conditions

\begin{tabular}{|c|c|c|c|}
\hline \multirow[b]{2}{*}{ Condition } & \multicolumn{3}{|c|}{ Study } \\
\hline & - Van den Bos [23\} & Ooijendijk et al. [25] & Van der Velden [24] \\
\hline $\begin{array}{l}\text { Chronic bronchitis } \\
\text { Other lung diseases (asthma etc.) } \\
\text { Sinusitis } \\
\text { Hay fever }\end{array}$ & $\begin{array}{l}\text { negative } \\
\text { negative } \\
-\end{array}$ & $\begin{array}{l}\text { - } \\
\text { negative } \\
\text { positive } \\
-\end{array}$ & $\begin{array}{l}\text { negative } \\
\text { negative } \\
\text { positive }\end{array}$ \\
\hline $\begin{array}{l}\text { Heart complaints, disorders } \\
\text { High blood pressure } \\
\text { Stroke, consequences of stroke } \\
\text { Varices } \\
\text { Haemorrhoids } \\
\text { Atherosclerosis } \\
\text { Vasculitis } \\
\text { Thrombosis }\end{array}$ & $\begin{array}{l}\text { negative } \\
\text { not signif. } \\
\text { not signif. } \\
- \\
- \\
- \\
-\end{array}$ & $\begin{array}{l}\text { unclear } \\
\text { not signif. } \\
\text { not signif. } \\
\text { U-shaped } \\
\text { not signif. } \\
\text { not signif. } \\
\text { not signif. } \\
\text { not signif. }\end{array}$ & $\begin{array}{l}\text { negative } \\
\text { negative } \\
\text { ne } \\
\text { negative } \\
\text { not signif. } \\
\text { not signif. } \\
-\end{array}$ \\
\hline $\begin{array}{l}\text { Stomach ulcer, duodenum ulcer } \\
\text { Stomach complaints } \\
\text { Large intestine complaints } \\
\text { Gallstones, other gallbladder and liver diseases } \\
\text { Hernia }\end{array}$ & $\begin{array}{l}\text { negative } \\
\text { negative } \\
-\end{array}$ & $\begin{array}{l}\text { negative } \\
\text { negative } \\
\text { not signif. } \\
\text { not signif. } \\
\text { not signif. }\end{array}$ & $\begin{array}{l}\text { \} negative } \\
\text { not signif. } \\
-\end{array}$ \\
\hline $\begin{array}{l}\text { Kidney stones } \\
\text { Kidney diseases } \\
\text { Chronic cystitis } \\
\text { Prostate complaints } \\
\text { Prolapse }\end{array}$ & $\begin{array}{l}\text { not signif. } \\
- \\
\text { not signif. }\end{array}$ & $\begin{array}{l}\text { not signif. } \\
\text { negative } \\
\text { not signif. } \\
\text { not signif- }\end{array}$ & $\begin{array}{l}- \\
\text { not signif. } \\
\text { negative } \\
-\end{array}$ \\
\hline $\begin{array}{l}\text { Diabetes } \\
\text { Thyroid disorders }\end{array}$ & $\begin{array}{l}\text { negative } \\
\text { not signif. }\end{array}$ & $\begin{array}{l}\text { negative } \\
\text { not signif. }\end{array}$ & $\begin{array}{l}\text { negative } \\
\text { positive }\end{array}$ \\
\hline $\begin{array}{l}\text { Back complaints, sciatica etc. } \\
\text { Rheumatic complaints, arthritis complaints }\end{array}$ & $\begin{array}{l}\text { negative } \\
\text { negative }\end{array}$ & $\begin{array}{l}\text { negative } \\
\text { negative }\end{array}$ & $\begin{array}{l}\text { negative } \\
\text { not signif. }\end{array}$ \\
\hline $\begin{array}{l}\text { Epilepsy } \\
\text { Other diseases of nervous system }\end{array}$ & \} negative & negative & \} not signif. \\
\hline Migraine, serious headache & not signif. & U-shaped & not signif. \\
\hline $\begin{array}{l}\text { Chronic skin disorders } \\
\text { Cancer } \\
\text { Accident, consequences of accident }\end{array}$ & $\begin{array}{l}\text { not signif. } \\
\text { not signif. } \\
\text { not signif. }\end{array}$ & $\begin{array}{l}\text { positive } \\
\text { not signif. } \\
\text { negative }\end{array}$ & $\begin{array}{l}\text { positive } \\
\text { unclear } \\
\text { unclear }\end{array}$ \\
\hline
\end{tabular}

- Not investigated or not reported.

Not signif. over-all test of differences not statistically significant $(P>0.05)$.

- Postal survey; Amsterdam elderly; $n=8244$; three occupational status categories.

'Netherlands Health Interview Survey (CBS); nationally representative sample; $n=43,414$; five occupational status categories.

'Health interview survey; nationally representative sample; $n=13,014$; four occupational status categories (self-employed and farmers excluded from analysis). 
Table 4. Male all-cause mortality by socio-economic group in the postwar period: results of studies at the individual level

\begin{tabular}{|c|c|c|c|c|c|}
\hline $\begin{array}{l}\text { First } \\
\text { author }\end{array}$ & Study design & $\begin{array}{l}\text { Period, } \\
\text { age group }\end{array}$ & Population & Socio-economic group & Relative Risk ${ }^{b}$ \\
\hline Wolff [38] & Cross-sectional & $1947-52,15-64$ & $\begin{array}{l}\text { Total } \\
\text { Amsterdam } \\
\text { population } \\
(N \approx 300,000)\end{array}$ & $\begin{array}{l}\text { Professionals, managers a.o. } \\
\text { Own account workers } \\
\text { Lower employees } \\
\text { Labourers }\end{array}$ & $\begin{array}{l}1.00 \\
1.14 \\
1.48^{*} \\
1.21^{*}\end{array}$ \\
\hline Schrama [39] & Cross-sectional & $1947-61,35-64$ & $\begin{array}{l}\text { Postal and } \\
\text { Telecommunication } \\
\text { Services } \\
(N=25,870)\end{array}$ & $\begin{array}{l}\text { Managers } \\
\text { Office personnel } \\
\text { Technical staff } \\
\text { Postal delivery men }\end{array}$ & $\begin{array}{l}1.00 \\
1.24^{*} \\
1.08 \\
1.00\end{array}$ \\
\hline Van Reek [40] & Cross-sectional & $1959-61,40-64$ & $\begin{array}{l}\text { Total national } \\
\text { population } \\
(N=1,303,068)\end{array}$ & $\begin{array}{l}\text { Professionals a.o. } \\
\text { Own account workers and } \\
\text { lower employees } \\
\text { Labourers }\end{array}$ & $\begin{array}{l}1.00 \\
1.15^{*} \\
1.12^{*}\end{array}$ \\
\hline Mares [41] & Longitudinal & $1953-80,40-65$ & $\begin{array}{l}\text { Civil servants } \\
\text { Amsterdam } \\
(N=1583)\end{array}$ & $\begin{array}{l}\text { Income level } 5 \text { (high) } \\
\text { Income level } 4 \\
\text { Income level } 3 \\
\text { Income level } 2 \\
\text { Income level } 1 \text { (low) }\end{array}$ & $\begin{array}{l}1.00 \\
1.10 \\
1.08 \\
1.15 \\
1.21\end{array}$ \\
\hline Doornbos [42] & Longitudinal & $1950-81,18^{d}$ & $\begin{array}{l}\text { National } 1932 \\
\text { birth cohort } \\
(N=78,505)\end{array}$ & $\begin{array}{l}\text { Educational level } 4 \text { (high) } \\
\text { Educational level } 3 \\
\text { Educational level } 2 \\
\text { Educational level } 1 \text { (low) }\end{array}$ & $\begin{array}{l}1.00 \\
1.15^{*} \\
1.22^{*} \\
1.49^{*}\end{array}$ \\
\hline Duykers [43] & Longitudinal & $\begin{array}{l}1960-85 \\
40-49 / 50-59^{4}\end{array}$ & $\begin{array}{l}\text { Town of Zutphen } \\
(N=856)\end{array}$ & $\begin{array}{l}\text { Professional a.o. } \\
\text { Own account workers } \\
\text { Lower employees } \\
\text { Labourers }\end{array}$ & $\begin{array}{r}1.00 / 1.00 \\
2.25 * / 0.91 \\
1.63 / 0.90 \\
2.07 * / 0.92\end{array}$ \\
\hline Appels [27] & Longitudinal & $1972-82,45-59$ & $\begin{array}{l}\text { Rotterdam } \\
(N=3365)\end{array}$ & $\begin{array}{l}\text { Professionals a.o. } \\
\text { Own account workers and } \\
\text { lower employees } \\
\text { Labourers }\end{array}$ & $\begin{array}{l}1.00 \\
1.84^{*} \\
2.02 *\end{array}$ \\
\hline
\end{tabular}

-For longitudinal studies the given age range refers to the beginning of the study period.

${ }^{b}$ Risk of dying relative to highest socio-economic group. Standardized for age.

'Excluding agricultural workers and miners respectively.

The death experience of this young cohort is principally formed in the years after 1965 .

'Because of strong interaction of the mortality effects of age and SES, Relative Risks by socio-economic group are presented for two different age-groups.

Significantly different from $1.00(P<0.05)$

Adapted from Kunst et al. [37].

not only been shown in the Netherlands Health Interview Survey (Table 1), but also in several other health interview surveys $[21,22]$. It should be noted that the number of reported health complaints, measured (as it is here) with a list of more and less serious symptoms and sensations, is probably not only a reflection of the presence of disease but may also be an indicator of psychosomatic problems.

\section{Morbidity}

Unfortunately, information on socio-economic differences in morbidity is almost completely limited to data on the prevalence of chronic conditions as reported in health interview surveys. Table 1 shows differences in over-all prevalence of chronic conditions as found in the Netherlands Health Interview Survey. The number of conditions per 100 persons is some $50 \%$ higher in the lowest educational category than it is in the highest. When income is used as an indicator of socio-economic status, the differences are smaller [9]. Socio-economic differences in the prevalence of chronic conditions have also been found in other health interview surveys $[21,23,24]$.

Recently a number of condition-specific analyses of these differences has been reported. For many conditions included in the questionnaires the prevalence is higher in lower socio-economic groups. Table 3 summarizes the results of these studies. For a number of conditions the association between prevalence and SES is negative in at least 2 of the 3 studies: chronic bronchitis and other lung diseases; heart disorders; a group of abdominal disorders; diabetes; back complaints; rheumatic complaints. Only one of these studies reports Relative Risks (Van den Bos [23]). The Relative Risks for the prevalence in the lowest vs the highest category mostly lie in the range between 1.10 and 1.30 (but note that only three categories were distinguished). The largest Relative Risk was found for chronic bronchitis (1.68).

The near-absence of positive associations in Table 3 should not distract from the few exceptions that do exist. Positive associations were sometimes found for sinusitis, hay-fever, thyroid disorders and chronic skin disorders [25]. In addition there is a number of conditions for which differences were apparently absent or entirely inconsistent. Surprisingly, these include accidents and consequences of accidents (see Ref. [26] for another study which did not find socio-economic differences in accidental injury).

As self-reports of chronic conditions are known to be inaccurate, it would be helpful to validate the differences as found in health interview surveys against the results of studies of medically ascertained conditions. Unfortunately, the only available studies 
of socio-economic variation in the incidence of medically ascertained conditions concern cardiovascular disease and chronic non-specific lung disease.

A $9 \frac{1}{2}$-year follow-up study of the incidence of cardiovascular disease among a group of 3365 Rotterdam men did not find statistically significant differences between socio-economic groups. It should be noted, however, that the period in which the study took place (1972-1982) may have included the well-known reversal from a positive to a negative association between ischaemic heart disease and socio-economic status [27].

A 25-year follow-up study of a group of Zutphen men did find statistically significant differences in the incidence of chronic non-specific lung disease (a Relative Risk of 1.82 for blue collar workers vs white collar workers) [28].

\section{Disability}

In 1986-1988 an extensive questionnaire on disability was included in the Netherlands Health Interview Survey. The results of this study indicate relatively large socio-economic differences in the prevalence of reported disability in the Dutch population. The data have only been published in an aggregated form, as the percentage of persons reporting one or more disabilities in walking, sitting down/getting up, sitting/standing, using arm or hand, balancing, seeing, hearing, speaking, endurance, and/or producing/retaining urine or faeces (Table 1). The prevalence of having one or more severe or very severe disabilities is three times larger in people with primary school only than it is in people with a university degree. No other health indicator in the Netherlands Health Interview Survey shows such a large degree of variation between socio-economic groups [13]. A gradient in the prevalence of disabilities is already present in children [16].

One of the potential consequences of disabilities is incapacity to work. In the Netherlands there is a comprehensive and compulsory insurance coverage of the financial consequences of health-related work incapacity. This insurance coverage consists of two parts: one for 'short-term' incapacity to work (less than 1 year), covered by the Ziektewet, and one for 'long-term' incapacity to work (following a 1-year Ziektewet-episode), covered by the Wet op de Arbeidsongeschiktheidsverzekering.

For short-term work incapacity reports on socioeconomic differences are not entirely consistent. In a registry covering a large sample of industrial and service oriented companies the incidence of shortterm work incapacity is higher in those with a lower occupational status or a lower educational level [29]. In a registry covering civil servants in Rotterdam, however, no clear differences were found [21]. The same applies to the Netherlands Health Interview Survey (Table 1), although it should be noted that the measure employed (percentage of persons reporting at least one episode of absence from work due to health problems during the last year) is crude and probably not very sensitive to variation in incidence [12].

The incidence of long-term work incapacity differs considerably between socio-economic groups. Studies of registry data covering an industrial population [30] and a population of state employees [31] respectively have shown this. In the former study, the incidence among employees with primary school only was 2.3 times that of employees with vocational college or university. Apparently socio-economic variation in the (first) occurrence of health problems causing work incapacity is smaller than that in the probability of a long duration of such episodes. This is also evident from the fact that the average duration of short-term work incapacity is much longer in employees with lower socio-economic status [21, 29]. Either the health problems simply differ in severity between socio-economic groups; or the possibility of returning to one's job while having health problems differs between socio-economic groups. Probably both explanations are true to some extent.

\section{Perceived general health}

People in higher socio-economic groups have a better over-all judgment of their health [9] (Table 1). Perceived general health shows a socio-economic gradient which is steeper than that of chronic conditions or health complaints but less steep than that of (very) severe disability. It is probably to be interpreted as a personal, weighted average of several aspects of health.

\section{Mortality}

For socio-economic differences in mortality, the density of information is relatively high, despite the absence of socio-economic data on the deceased in national mortality statistics. The available information derives from a number of ecological studies as well as from a small number of individual level studies. Although ecological studies may be subject to bias, the results are presented here as indirect evidence on socio-economic health differences at the individual level, because they are mostly consistent both internally and with the results of individual level studies.

The most widely known ecological study is an analysis of mortality differences between neighbourhoods in Amsterdam in 1972-1976. This study was undertaken at a time when practically all that was known about socio-economic mortality differences in the Netherlands was thought to be outdated. The more or less unexpected observation of higher mortality in deprived areas was considered to be an indication of the persistence of socio-economic mortality differences in the Netherlands [32]. A replication of this study with data from the years 1977-1983 produced essentially the same results [33], as did neighbourhood mortality studies in The Hague [34], Rotterdam [35] and Arnhem [36]. 
At another level of aggregation, that of 40 regions covering the complete territory of the Netherlands, there was also a strong association between socioeconomic indicators and mortality in 1980-1984. Although this applies to both sexes, the association was stronger for males. An analysis of the 16 largest causes of death showed statistically significant, negative associations for stomach cancer, diabetes mellitus, ischaemic heart disease, cerebrovascular disease and traffic accidents. The associations were statistically significant and positive for lung cancer, breast cancer, prostate cancer and arterial diseases [37].

In addition to providing details on specific causes of death, this regional study also provided evidence on trends in socio-economic mortality differences. The association between mortality and socioeconomic indicators has not always been negative, at least not for males. For females, the association was already weakly negative in the early 1950s. For males, however, there was a statistically significant, positive association between all-cause mortality and socio-economic indicators in 1950-1954 and 1960-1964, after which it gradually changed into a negative association. This is due to changes in the association for several causes of death, including lung cancer (from strongly positive to weakly positive), diabetes mellitus (from positive to negative), ischaemic heart disease (from positive to negative), cerebrovascular disease (from positive to negative), and traffic accidents (from weakly negative to strongly negative). Some of these changes closely resemble those observed in individual level studies in other countries [37].

Table 4 provides an overview of the results of all individual level studies of adult mortality from the postwar period in the Netherlands. Recently, the results of four (retrospective) cohort studies were published, covering follow-up periods up to the early 1980s. These recent studies provided indications of higher mortality rates in the lower socio-economic groups. The Relative Risks of dying for the lowest vs the highest socio-economic group varied between $c a$ 1.20 and $c a 2.00$. This may be due to differences in study population, time-period covered, and socioeconomic classification, and thus should not be overinterpreted [27, 41-43]. The only exception in this pattern of higher mortality rates in the lowest SESgroup is formed by the oldest of the two cohorts in the Zutphen study, in which there was no socio-economic variation in death rates at all. It is important to note that this cohort on average is much older than the other study populations on which information is included in Table 4. Socio-economic differences in mortality are generally thought to be smaller in the highest age-groups [43].

A comparison of these recent studies with older studies mentioned in Table 4 shows that the highest socio-economic group always had the lowest mortality rates, but that in the 1950s and early 1960s the socio-economic differences were small and inconsist- ent, with (white collar) employees having higher mortality rates than blue collar workers [38-40]. This supports the evidence on changing associations from the regional study mentioned above.

A recent individual level study of perinatal mortality in Amsterdam did not find consistent differences between socio-economic groups [44]. An analysis of the association between perinatal mortality and socio-economic indicators at the regional level, however, did find higher rates in poorer regions [45]. The differences in birth weight shown in Table 1 also suggest that perinatal mortality may be associated with socio-economic position. It is as yet unclear whether the current inconsistencies should be interpreted as evidence for a reduction of socioeconomic differences in perinatal mortality: in national individual level studies from 1952/3 [46] and 1961 [47] rates were (still?) clearly higher among babies born from parents with a lower socioeconomic position.

\section{THE EXPLANATION OF SOCIO-ECONOMIC HEALTH DIFFERENCES IN THE NETHERLANDS}

The explanation of SEHD in the Netherlands is likely to be broadly comparable to that of SEHD in other industrialized countries, although the contribution of specific mechanisms or factors may of course differ to a smaller or larger extent. We hypothesize, therefore, that SEHD in the Netherlands are due to the following mechanisms:

-An effect of current socio-economic status on health by way of specific risk factors which are differentially distributed across socio-economic groups.

Data on the differential distribution of risk factors in the Netherlands, to be reviewed below, suggest that this mechanism makes a substantial contribution to the explanation of SEHD, as it does in other countries.

-An effect of socio-economic circumstances in childhood on adult health by way of a compromised health stock at the start of adult life.

There is a growing body of literature, both from the U.K. and from Scandinavian countries, which suggests that this may be an important mechanism. Differences in adult height in the Netherlands support the notion of a compromised health stock at the start of adult life but studies in which current socio-economic status, current health, socio-economic background and health stock are simultaneously analyzed are still awaited.

-An effect of health on socio-economic status by way of health-related selection during social mobility.

Studies from the U.K. have consistently shown that although such selection does occur, both during intergenerational and 
intragenerational social mobility, the contribution to the explanation of SEHD is very modest. No information which directly concerns the issue is available yet in the Netherlands. The fact that differences by education (which cannot be biased by health-related selection during intragenerational social mobility) are as large or larger as those by income or occupational status suggests that this type of explanation is not likely to be very important.

Table 5 presents an overview of evidence related to the first mechanism: socio-economic differences in the prevalence of a number of risk factors in the Netherlands. Direct evidence related to the other two mechanisms is almost completely lacking in the Netherlands.
Differential distribution of health-related behaviour and associated factors

Smoking is more prevalent in the lower socio-economic groups. Table 5 contains data from a recent survey (1989-1990) which suggest that there is not a smooth gradient of increasing prevalence rates from high to low SES. The highest prevalence rates of smoking are found in the second lowest SES-group. In addition, the differences in prevalence rates of smoking are not particularly large [48]. In an analysis of changes in the association between SES and smoking between 1958 and 1982, using data from a number of successive national surveys, it was shown that the negative association probably dates back to the late 1950s/early 1960s for males, and to the 1970 s for females. Before that, smoking was more prevalent in higher socio-economic groups [52]. This

Table 5. A summary of survey data on socio-economic differences in the prevalence of risk factors

\begin{tabular}{|c|c|c|c|c|c|}
\hline Risk factor & Reference & Period & Sample & Socio-economic group & Measure \\
\hline Percentage current smokers & [48] & $\frac{\text { IV } / 1989}{\text { III } / 1990}$ & $\begin{array}{l}\text { National } \\
(n=20445)\end{array}$ & $\begin{array}{l}\text { SES A (high)" } \\
\text { SES BB } \\
\text { SES BO } \\
\text { SES C } \\
\text { SES D (low) }\end{array}$ & $\begin{array}{l}30 \\
33 \\
35 \\
38 \\
33\end{array}$ \\
\hline Fat consumption (energy $\%)^{b}$ & [49] & $1987-1988$ & $\begin{array}{l}\text { National } \\
(n=4134)\end{array}$ & $\begin{array}{l}\text { SES high" } \\
\text { SES middle } \\
\text { SES low }\end{array}$ & $\begin{array}{l}40.0 \\
40.1 \\
41.5\end{array}$ \\
\hline $\begin{array}{l}\text { Ratio of poly-unsaturated to } \\
\text { saturated fatty acids }\end{array}$ & [49] & $1987-1988$ & $\begin{array}{l}\text { National } \\
(n=4134)\end{array}$ & $\begin{array}{l}\text { SES high" } \\
\text { SES middle } \\
\text { SES low }\end{array}$ & $\begin{array}{l}0.390 \\
0.435 \\
0.445\end{array}$ \\
\hline Alcohol consumption (energy $\%)^{b}$ & [49] & $1987-1988$ & $\begin{array}{l}\text { National } \\
(n=4134)\end{array}$ & $\begin{array}{l}\text { SES high" } \\
\text { SES middle } \\
\text { SES low }\end{array}$ & $\begin{array}{l}5.0 \\
4.2 \\
3.2\end{array}$ \\
\hline $\begin{array}{l}\text { Percentage overweight } \\
(\text { BMI } \geq 27)^{b c}\end{array}$ & [11] & $198 !-1983$ & $\begin{array}{l}\text { National } \\
(n=20,000)\end{array}$ & $\begin{array}{l}\text { University } \\
\text { Vocational colleges } \\
\text { Secondary (vocational) training } \\
\text { Junior vocational training } \\
\text { Primary school }\end{array}$ & $\begin{array}{r}8 \\
10 \\
13 \\
18 \\
25\end{array}$ \\
\hline $\begin{array}{l}\text { Percentage having had }>1 \\
\text { holiday in last year }\end{array}$ & {$[50]$} & 1983 & $\begin{array}{l}\text { National } \\
(n=3993)\end{array}$ & $\begin{array}{l}\text { Higher occupations } \\
\text { Middle employees } \\
\text { Lower employees } \\
\text { Labourers }\end{array}$ & $\begin{array}{l}48 \\
35 \\
24 \\
16\end{array}$ \\
\hline $\begin{array}{l}\text { Percentage reporting to have } \\
\text { "heavy' work }\end{array}$ & {$[50]$} & 1983 & $\begin{array}{l}\text { National } \\
(n=1750)\end{array}$ & $\begin{array}{l}\text { Higher occupations } \\
\text { Middle employees } \\
\text { Lower employees } \\
\text { Labourers }\end{array}$ & $\begin{array}{l}10 \\
12 \\
12 \\
37\end{array}$ \\
\hline $\begin{array}{l}\text { Average number of negative } \\
\text { life events in last year }\end{array}$ & [51] & $1988 / 1989$ & $\begin{array}{l}\text { National } \\
(n=2716)\end{array}$ & $\begin{array}{l}\text { University } \\
\text { Vocational colleges } \\
\text { Intermediate } \\
\text { Junior (vocational) training } \\
\text { Primary school }\end{array}$ & $\begin{array}{l}0.64 \\
0.66 \\
0.66 \\
0.67 \\
0.71\end{array}$ \\
\hline $\begin{array}{l}\text { Percentage reporting possibility to } \\
\text { discuss personal problems } \\
\text { with friends/acquaintances }\end{array}$ & {$[51]$} & $1988 / 1989$ & $\begin{array}{l}\text { National } \\
(n=2716)\end{array}$ & $\begin{array}{l}\text { University } \\
\text { Vocational colleges } \\
\text { Intermediate } \\
\text { Junior (vocational) training } \\
\text { Primary school }\end{array}$ & $\begin{array}{l}77 \\
66 \\
61 \\
48 \\
39\end{array}$ \\
\hline $\begin{array}{l}\text { Percentage with GP contact } \\
\text { in last yeard }\end{array}$ & [9] & $1983-1985$ & $\begin{array}{l}\text { National } \\
(n=22,445)\end{array}$ & $\begin{array}{l}\text { University } \\
\text { Vocational colleges } \\
\text { Secondary (vocational) education } \\
\text { Junior (vocational) training } \\
\text { Primary school }\end{array}$ & $\begin{array}{l}69.5 \\
74.6 \\
74.7 \\
74.0 \\
73.2\end{array}$ \\
\hline $\begin{array}{l}\text { Percentage with consultant contact } \\
\text { in last yeard }\end{array}$ & [9] & $1983-1985$ & $\begin{array}{l}\text { National } \\
(n=22,445)\end{array}$ & $\begin{array}{l}\text { Primary school } \\
\text { University } \\
\text { Vocational colleges } \\
\text { Secondary (vocational) education } \\
\text { Junior (vocational) training } \\
\text { Primary school }\end{array}$ & $\begin{array}{l}73.2 \\
44.3 \\
41.0 \\
42.9 \\
37.8 \\
36.1\end{array}$ \\
\hline
\end{tabular}

- Socio-economic status indicator based on occupational and educational level.

${ }^{b}$ Reported sex-specific rates were averaged to derive a general prevalence rate.

'Prevalence rates are standardized for age differences.

Standardized for age, sex and (reported) health status. 
may explain why lung cancer mortality still is higher in more wealthy regions (see preceding section).

Dietary habits differ between socio-economic groups too. According to a recent (1987-1988) food consumption survey, persons with a lower socioeconomic status less often follow special dietary rules, less often use nutritional supplements, and more often skip breakfast. In the lower SES groups a higher fat intake was observed. However, the contribution of saturated fatty acids to energy intake did not differ among SES groups, whereas the P:S ratio (ratio of poly-unsaturated to saturated fatty acids) was even higher in the low SES group (Table 5). The net effect of these differences in fat consumption, the health effects of which are in opposite directions, is unclear. There were no differences in the intake of cholesterol, mono- and disaccharides and dietary fibre [49]. In a further analysis of these data, life style patterns consisting of only (un)favourable habits (with respect to diet, smoking, alcohol consumption and body weight) were shown not to be exclusive for any SES group, which confirms the impression that the differences between SES groups are not as consistent as generally thought [53].

According to this same food consumption survey alcohol consumption, measured as percentage of daily intake of energy (Table 5), is higher in the higher SES-groups. This is the result of both a lower proportion of abstainers and a higher proportion of heavy drinkers [41]. Although other studies differ on the distribution of specific categories of drinkers, they all suggest that average intake of alcohol is higher in the higher SES-groups $[22,54]$.

High blood pressure and high serum cholesterol are probably not strongly associated with SES. This impression is based on preliminary results from a 1987 study of 6319 men and women aged 20-60 in Amsterdam, Doetinchem and Maastricht. Among men there is no clear association between educational level and either systolic blood pressure or serum cholesterol. Among women, only serum cholesterol is lower in the higher educational categories [55]. The findings of this study are broadly similar to those of earlier studies, partly to be discussed below $[27,43,56]$.

Obesity, on the other hand, has repeatedly been shown to be more prevalent in the lower socio-economic groups [11,57, 58]. In an interesting analysis of trends in the association between socio-economic status and body mass index among 18-year-old conscripts it was found that in the late 1930s and in the 1950 s boys with a higher socio-economic status still had a higher body weight. The reyersal took place in the 1960s [20].

\section{Differential distribution of material living conditions}

On an international scale income differences in the Netherlands are relatively small. Surveys do nevertheless show substantial differences in living conditions. The frequency of e.g. having a car, having adequate housing and having regular holidays is higher in the higher SES-groups [50]. As an illustration Table 5 contains data on having regular holidays. Whether these differences directly or indirectly affect health is still a matter of speculation.

Working conditions are generally much less favourable in lower socio-economic groups. Table 5 contains data on differences in having 'heavy' work, but differences in many other aspects, such as exposure to noise, dirt and danger, are similar [50].

\section{Differential distribution of psychosocial living con- ditions}

The exposure to psychosocial stressors probably also is higher in lower socio-economic groups. As shown in Table 5, the average number of negative life events is higher among those with a lower education, although the magnitude of the differences is not striking [51]. Chronic stressful circumstances, associated with financial worries, lack of work satisfaction or problems in private life, are probably also more common in lower socio-economic groups $[50,59]$.

At the same time there is more often a lack of social support in the same groups, which may increase their vulnerability for the effects of these stressors. As an example, Table 5 shows the percentage reporting to have a possibility of discussing personal problems with friends and acquaintances. The same pattern is found for discussing problems with family-members [51].

\section{Differential distribution of supply/use of health care}

There are no clear socio-economic differences in the use of preventive health centres for infants and toddlers. The percentage of mothers visiting a centre with their child is, if anything, slightly lower in the higher educational groups $[60,61]$.

When differences in health status are taken into account, there are no clear differences in the frequency of general practitioner consultations between socio-economic groups (Table 5) [9]. Both the 'adequacy' and the nature of these visits, however, differ considerably.

In a study of illness behaviour among more than 3000 inhibitants of Nijmegen and its surroundings the 'adequacy' of general practitioner visits was assessed by an expert panel, which judged whether the somatic complaints reported by the study participants made a general practitioner visit necessary. It was shown that both 'underconsumption' (not visiting a GP when the complaints indicated that such a visit was necessary) and 'overconsumption' (vice versa) were more common in the lower socio-economic groups [62]. In a further analysis of these findings these differences could not be explained by the degree of 'protoprofessionalization' of the study participants [63].

The nature of general practitioner visits differs considerably between socio-economic groups too. Persons with a higher socio-economic status more 
often visit their general practitioners for preventive instead of curative purposes. The actions taken by the general practitioner also are different: patients with higher socio-economic status less frequently receive a drug prescription, and more frequently are referred to a consultant [64].

Not surprisingly then, after taking into account differences in health status, persons with a higher socio-economic status report more visits to consultants (Table 5) and physiotherapists [65]. On the other hand, there are no clear differences in the frequency of hospital admissions [9].

Using 1981 and 1982 data from the Netherlands Health Interview Survey, a comprehensive analysis was made of equity in the delivery of health care services. An aggregate measure of health care 'benefits' was derived by weighting general practitioner visits, consultant visits and in-hospital days with their respective monetary costs. After standardization for differences in age, sex, chronic conditions and perceived general health the benefits were slightly below average in the lowest income quintile, and slightly above average in the third (middle) income quintile. The other income quintiles received an amount of health care corresponding closely with the amount of 'need', as measured by the four variables mentioned above [66].

Whether differences in supply or use of health care contribute to the explanation of SEHD is difficult to say, because the health effects of different health care consumption patterns are largely unknown. There is one recent study which directly investigated differences in medical care outcomes between socioeconomic groups. In 137 patients suffering from type II diabetes mellitus metabolic control was found to be worse, and the total number of acute disorders of glucose metabolism in the past two years to be larger, in the lower socio-economic groups. These differences could not be explained by some crude measures of health care provision, such as the type of care provider or the frequency of control visits [67].

Simultaneous analyses of socio-economic status, risk factors and health problems

Over the past few years, five studies were published in which the contribution of specific risk factors to socio-economic health differences was quantified. Three of these studies (mainly) concerned health complaints, and two concerned mortality. Table 6 presents an overview of the results. Unfortunately, the studies are very different in design, in risk factors included in the analysis, and in the statistical methods. A straightforward comparison of the résults is therefore impossible, but each study in itself provides some valuable insights.

In an analysis of data from a health interview survey $(n=c a 1200)$ held in Rotterdam it was found that socio-economic differences in the number of health complaints could partly be explained by differ- ences in smoking and the number of visits to a general practitioner. The latter variable should be interpreted as an indicator of health status, so that the only relevant finding here concerns smoking. The contribution of smoking to the explanation of the differences in reported health complaints was, however, rather small [21].

In an analysis of questionnaire data concerning healthy employees $(n=c a 1000)$ of a number of companies in Zuid Limburg, smoking, alcohol consumption and a number of working conditions could be related to SES and the number of health complaints. Smoking explained a small part of the variation in health complaints, and alcohol consumption did not contribute at all to the explanation. Working conditions, however, especially lack of regulatory possibilities, made a very substantial contribution [68].

The third study of socio-economic status, risk factors and health complaints $(n=245)$ concerned a different outcome variable: an index based on the number of reported somatic conditions, positive affect as measured by Bradburn's Affect Balance Scale, and the number of psychological symptoms as measured by the General Health Questionnaire. A path analysis was used to reveal the complex interrelationships between socio-economic status, a number of risk factors and the health index. The single most important risk factor in this study was neuroticism, which appears to explain part of the differences in health as measured by the index [69].

These three studies thus yield rather different results. It is not very surprising that smoking, although its prevalance differs between socio-economic groups, did not contribute substantially to differences in health complaints. Smoking is probably not an important risk factor of psychosomatic problems. This is of course even more so in a study population consisting of healthy employees: variation in health complaints within such a selective group is likely to be due to psychosocial stress. This interpretation is supported by the fact that lack of regulatory possibilities is an important intermediary factor in this study. The third study adds another argument for the importance of psychological factors in the explanation of socio-economic differences in reported health complaints.

The two studies concerning mortality were already mentioned in Table 4 (Duykers [43] and Appels [27]). The first of these is a small cohort study of Zutphen men, in which variation in mortality between socioeconomic groups was found in the youngest of two age-groups only. The specific risk factors included in the baseline measurement of this study were Body Mass Index [higher in higher socio-economic groups (!)], systolic blood pressure (no differences), cigarette smoking (no differences) and serum cholesterol (no differences) Not surprisingly, a multivariate analysis showed that these risk factors did not contribute at 
Table 6. Overview of results from explanatory studies

\begin{tabular}{|c|c|c|c|c|c|}
\hline $\begin{array}{l}\text { First } \\
\text { author }\end{array}$ & Study design & $\begin{array}{l}\text { Period, } \\
\text { age group }\end{array}$ & Population & Specific risk factors" & Health outcome \\
\hline $\begin{array}{l}\text { Uniken } \\
\text { Venema }[21]^{b}\end{array}$ & Cross-sectional & $1987,16-69$ & $\begin{array}{l}5 \text { Rotterdam neighbour- } \\
\text { hoods } \\
(n \approx 1200)\end{array}$ & $\begin{array}{l}\text { Housing } \\
\text { GP visits } \\
\text { Alcoholuse } \\
\text { Number of children } \\
\text { Consultant visits } \\
\text { Drug use } \\
\text { Smoking } \\
\text { Sports } \\
\text { Body Mass Index }\end{array}$ & $\begin{array}{l}\text { Health complaints } \\
\text { (VOEG)-score }\end{array}$ \\
\hline Schröer [58] & Cross-sectional & ca. $1980,15-64$ & $\begin{array}{l}\text { Healthy employees of } \\
\text { Zuid Limburg } \\
\text { companies } \\
(n=807)\end{array}$ & $\begin{array}{l}\text { Smoking } \\
\text { Alcohol use } \\
\text { Routine work } \\
\text { Long working hours } \\
\text { Unfavourable physical } \\
\text { working conditions } \\
\text { Lack of regulatory } \\
\text { possibilities }\end{array}$ & $\begin{array}{l}\text { Health complaints } \\
\text { (VOEG)-score }\end{array}$ \\
\hline Ranchor $[69]^{\mathrm{C}}$ & Longitudinal & $\begin{array}{l}1970-1984 \\
30-73\end{array}$ & $\begin{array}{l}\text { National sample } \\
(n=245)\end{array}$ & $\begin{array}{l}\text { Social background } \\
\text { Health during childhood } \\
\text { General health } 1970 \\
\text { Neuroticism } \\
\text { Self esteem } \\
\text { Locus of control } \\
\text { Smoking } \\
\text { Alcohol use } \\
\text { Psychosocial stress } \\
\text { Social support } \\
\text { Medical attitudes } \\
\text { Illness behavior }\end{array}$ & Health status index ${ }^{d}$ \\
\hline Duykers [43] & Longitudinal & $\begin{array}{l}1960-1985 \\
40-49^{c}\end{array}$ & $\begin{array}{l}\text { Zutphen men } \\
(n \approx 450)\end{array}$ & $\begin{array}{l}\text { Body Mass Index } \\
\text { Systolic blood pressure } \\
\text { Cigarette smoking } \\
\text { Serum cholesterol }\end{array}$ & Mortality \\
\hline Appels [27] & Longitudinal & $\begin{array}{l}1973-1982 \\
45-59^{e}\end{array}$ & $\begin{array}{l}\text { Rotterdam men } \\
(n=3365)\end{array}$ & $\begin{array}{l}\text { Smoking } \\
\text { Body Mass Index } \\
\text { Diastolic blood pressure } \\
\text { Systolic blood pressure } \\
\text { Serum cholesterol } \\
\text { Marital status }\end{array}$ & Mortality \\
\hline
\end{tabular}

Specific risk factors included in a multivariate analysis with SES and health outcome. Underlined risk factors contributed substantially to the relationship between SES and health outcome. Due to differences between studies in type of analysis, results are not strictly comparable.

${ }^{b}$ This study included several analyses, of which the analysis of health complaints was selected for this table.

'This study used a path analysis. The $a$ priori model which was specified for the analysis of course heavily influences the results.

'An additive index consisting of the number of reported somatic conditions, positive affect as measured by Bradburn's Affect Balance Scale, and the General Health Questionnaire Score, all measured in 1984.

'Age at baseline measurement.

all to the elevated mortality risks in the lowest socio-economic groups [43].

In a cohort study of more than 3000 Rotterdam men clear socio-economic differences in all-cause mortality were found. The specific risk factors included in the base line measurement of this study were Body Mass Index (slightly higher in higher socio-economic groups), diastolic blood pressure (slightly higher in higher socio-economic groups), systolic blood pressure (no differences), smoking (more prevalent in lower socio-economic groups), serum cholesterol (slightly higher in higher socioeconomic groups) and marital status (more not-married in lower socio-economic groups). A multivariate analysis showed that the differential distribution of these risk factors (i.e. smoking and marital status) accounted for a substantial part of the mortality differences. Inclusion of these factors in the model reduced the Relative Risk of dying of the lowest SES-group from 2.02 to 1.67 [27].

The results of these mortality studies are of course heavily dependent on the nature and degree of socioeconomic variation in specific risk factors at the base line measurement. The generalizability of their findings to the explanation of current socio-economic mortality differences in the Netherlands is limited by the fact that the current distribution of risk factors in the Dutch population is rather different, especially with respect to Body Mass Index (both studies) and smoking (the Zutphen study).

\section{DISCUSSION}

At a very general level of description the pattern of socio-economic health differences in the Netherlands closely resembles that observed in other industrialized 
countries: SEHD are a generalized phenomenon, encompassing anthropometric characteristics like birth weight and body height, health complaints, chronic conditions, disability, long-term work incapacity, perceived general health, and adult mortality. Although condition-specific studies are rare and possibly subject to bias, it seems likely that differences in prevalence exist for many conditions, and that differences in mortality exist for many causes of death. Even the recent evolution of SEHD may resemble that observed elsewhere: there is evidence for a widening of mortality differences, and for a reduction of differences in children's body height.

The interesting question of course is whether there are differences with other countries at a more specific level of description, for example concerning the exceptions or the magnitude of the inequalities. This question immediately reveals the weaknesses in the current knowledge on SEHD in the Netherlands. We simply do not know with certainty whether there are any exceptions to the general rule of more health problems in lower socio-economic groups, and for many health problems we simply do not know what the exact magnitude of the differences is.

In this review we encountered several possible exceptions to the general pattern: children's body height; prevalence of some chronic conditions; incidence of short-term work incapacity; perinatal mortality. The fact that inconsistent findings on these health problems were reported may, however, also be due to aspects of the study designs, such as small sample size, selective samples, biased self-reports etcetera.

An assessment of the magnitude of SEHD in the Netherlands is hampered by the lack of nationally representative and recent data on socio-economic variation in mortality, which is the traditional yardstick in this area. The four recently published cohort studies (Table 4) all involved selective samples, either geographically or with regard to age, not mentioning the fact that they only included (or reported on) males. In addition, they mostly cover extensive timeperiods. The Relative Risks of dying in the lowest vs the highest socio-economic group varied between ca 1.20 and $c a 2.00$. This is not very helpful in deciding whether differences in the Netherlands are smaller or larger than those reported for other countries, because this range includes the variation observed between other industrialized countries. There have been several studies analyzing international differences in mortality variation according to socio-economic group: between Finland, England and Wales and France [70], between Finland, Norway, Sweden, Denmark, England and Wales and Hungary [71], and betweeen England and Wales and Sweden [72]. These comparisons all involve national mortality statistics by socio-economic status and considerable regrouping of data to permit comparisons to be made. For males, the Relative Risks of dying in the lowest vs the highest occupational group vary between $c a 1.20-1.50$ in a number of Scandinavian countries (excuding Finland) and $c a 2.00$ in England and Wales and Finland. It is only in France that the differences are probably larger.

For health problems reported in health interview surveys, however, the Netherlands do have nationally representative and recent data (Table 1). There have been several examples of studies analysing international differences in inequality of reported health problems: between the United Kingdom and France [73], between the Nordic countries [74], and between Britain, Norway, Denmark, Hungary and France [75]. Such comparisons are fraught with difficulties, because the comparability of data is very limited. This is due to variation in sampling, socio-economic classification, health problem questionnaires, way of reporting findings etcetera. Nevertheless, at first sight the differences shown in Table 1 do at least not seem to be much smaller than those observed in other countries. For example, the comparison between Nordic countries, based on the Scandinavian welfare survey held in 1972 in Denmark, Norway, Sweden and Finland, showed that the ratio of the age-standardized prevalence of self-reported chronic illness of the lowest vs the highest income quintile was 1.07 in Denmark, 1.26 in Norway, 1.28 in Sweden and 1.75 in Finland [71]. In the Netherlands, the ratio of the lowest vs the highest income group ( $\approx$ sextiles) of this health measure is 1.25 (Table 1). Further study, probably involving reanalysis of recent health interview survey data from several countries, including the Netherlands, is necessary before firm conclusions can be drawn.

Whatever the exact magnitude of the differences in the Netherlands, the Relative Risks mostly imply 'weak associations' from a technical-epidemiological point of view. In studies categorizing the study population in 4-6 hierarchically ordered socio-economic groups, the Relative Risks (of the lowest vs the highest socio-economic group) lie between 1 and 2 for many health problems (prevalence of health complaints, prevalence of chronic conditions, mortality). Only disability and long-term work incapacity show higher Relative Risks. Such low Relative Risks have important implications for the conduct of studies, which should have sufficient power and should also avoid misclassification as much as possible. The recent recommendations of a committee reviewing the measurement of socio-economic status in epidemiological and socio-medical studies, may help in avoiding misclassification, as well as in enhancing the comparability of results from different investigations [76].

From a public health point of view, Relative Risks between 1 and 2 may be considered substantial if they affect large segments of the population. This is of course the case here. The calculation of Population Attributable Risk measures may illustrate this. The Population Attributable Risk (PAR) can be 
interpreted as the fraction of the over-all frequency (incidence rate, prevalence rate) of the health problem in the population which is attributable to exposure to low SES (lower than a reference category, i.e. the highest SES-group). If one calculates the PAR measure on the data presented in Tables 1 and 3, it is typically in the range of 0.25 to 0.40 . For example, the PAR of a lower than university education for a less than 'good' perceived general health is 0.35 (Table 1).

On the basis of our review of the differential distribution of risk factors it is hypothesized that the higher frequency of health problems in lower socioeconomic groups in the Netherlands can (partly) be explained by differences in:

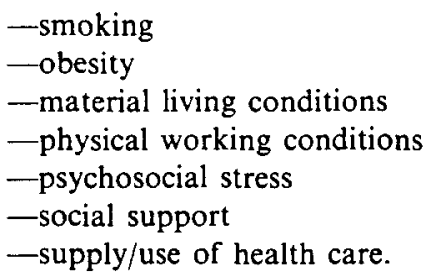

It is equally important to note that it can probably not be attributed to differences in the prevalence of:

-high alcohol consumption

-high blood pressure

一high serum cholesterol.

The role of dietary habits is unclear, some unfavourable habits (e.g. a high fat intake) being more common, and others (e.g. a high intake of poly-unsaturated fatty acids) being less common in lower socio-economic groups.

More simultaneous analyses of SES, risk factors and health problems are necessary to quantify the contribution of specific factors to SEHD. The simultaneous analyses which have been carried out so far have produced promising results, but they have also taught us that the informative value heavily depends on:

-comprehensiveness with regard to the risk factors investigated;

-representativeness of the risk factor distribution for the current situation in the Netherlands.

This review has shown that knowledge concerning SEHD in the Netherlands is increasing rapidly. The national research programme mentioned in the introduction has made a substantial direct contribution to this increase in knowledge. Of the studies mentioned in the tables many were funded by this programme or its small-scale predecessor. This includes studies mentioned in Table 3 [25], Table 4 [27, 42, 43], Table 5 [49] and Table $6[21,27,43,68,69]$, as well as a number of studies mentioned in the text. On the other hand, there is also a considerable contribution from studies funded from other sources, which shows that the interest in SEHD among researchers is not limited to participants in the programme. The latter may be seen to act as a catalyst.
For the years to come we list the following recommendations for further study.

1. More and more powerful descriptive data should be generated, in order to resolve current inconsistencies and to obtain a quantitatively exact picture of SEHD in the Netherlands. This can be achieved through:

a. Introduction of socio-economic status indicators in routine health data collecting systems.

b. Uniform measurement of socio-economic status in as many epidemiological and socio-medical studies as possible.

c. Commissioning special studies to resolve central issues. This includes the question whether SEHD in the Netherlands differ from those in other countries.

2. More and more powerful explanatory data should be generated. This requires

a. Simultaneous analyses of SES, risk factors and health problems, investigating the hypotheses mentioned earlier and following the specifications given with regard to, comprehensiveness and representativeness.

But at the same time, new hypotheses could be generated and old hypotheses be modified by:

b. Continuous monitoring of socio-economic differences in the prevalence of established and possible risk factors.

Acknowledgements - For this review extensive use has been made of the facilities of the "Documentatiecentrum Sociaaleconomische Gezondheidsverschillen" (Documentation Center for Socio-Economic Health Differences) which is supported financially by the Ministry of Welfare, Public Health and Culture, Rijswijk, the Netherlands.

M. Mootz (Sociaal en Cultureel Planbureau), J. van der Velden (Nederlands Instituut voor Eerstelijnsgezondheids. zorg), B. Baan (Stichting Volksgezondheid en Roken) and W. T. M. Ooijendijk (Nederlands Instituut voor Praeventieve Gezondheidszorg TNO) kindly supplied unpublished data for this review.

J. C. van Wieringen (Gemeentelijke Geneeskundige en Gezondheids Dienst Utrecht) and K. F. A. M. Hulshof (TNO-Voeding) kindly assisted in the interpretation of their published findings.

\section{REFERENCES}

1. Mackenbach J. P. and Maas P. J. van der. Social inequality and differences in health: a survey of the principal research findings. In Socio-economic Inequalities in Health. Reeks Sociaal-economische Gezondheidsverschillen no. 2 (Edited by Gunning-Schepers L. J. et al.). Ministerie van Welzijn, Volksgezondheid en Cultuur, Rijswijk, 1989. Mackenbach J. P. and Maas P. J. van der. Sociale ongelijkheid en verschillen in gezondheid. In De Ongelijke Verdeling van Gezondheid. WRR Voorstudies no. V58. Staatsuitgeverij, 's-Gravenhage, 1987.

2. Stronks K. and Mackenbach J. P. Recent Nederlands onderzoek op het gebied van sociaal-economische 
gezondheidsverschillen. Tijdschr. Soc. Gezondheidsz. 66 , 349-354, 1988.

3. Spruit I. P. Health and social inequities in the Netherlands. Soc. Sci. Med. 31, 319-329, 1990.

4. Inequalities in Health (the Black Report) (Edited by Townsend P. et al.). Penguin, Harmondsworth, 1982.

5. World Health Organization. Targets for Health for All WHO Regional Office for Europe, Copenhagen, 1985

6. Anonymous. Nota 2000, over de ontwikkeling van gezondheidsbeleid; feiten, beschouwingen en beleids. voornemens. Tweede Kamer, vergaderjaar 1985-1986, 19500 , nrs. $1-2$.

7. Wetenschappelijke Raad voor het Regeringsbeleid. De Ongelijke Verdeling van Gezondheid. WRR Voorstudies No. V58. Staatsuitgeverij, 's-Gravenhage, 1987

8. Programmacommissie Sociaal-Economische Gezondheidsverschillen. Een Onderzoeks-programma voor de Periode $1989 \mathrm{t} / \mathrm{m}$ 1993. Reeks Sociaal-economische Gezondheidsverschillen no. 3: Ministerie van Welzijn, Volksgezondheid en Cultuur, Rijswijk, 1989.

9. Centraal Bureau voor de Statistiek. Netherlands Health Interview Survey 1981-1985. Staatsuitgeverij, Den Haag, 1988.

10. Swinkels H. Geboortelengte en-gewicht, GE 1985 Mndber. Gezondh. (CBS) 1, 4-12, 1989.

11. Sonsbeek J. L. A. van. Nederlanders, gemeten en gewogen. Lengteverschillen en onder-en overgewicht bij de volwassen bevolking. Mndber, Gezondh. (CBS) 6 , $5-17,1985$

12. Brekel E. J. G. van den. Ziekteverzuim van de beroepsbevolking 1981-84. Mdnber. Gezondh. (CBS) 4, 5-32, 1986

13. Centraal Bureau voor de Statistiek. Lichamelijke Beperkingen bij de Nederlandse Bevolking 1986/1988. SDU-uitgeverij, 's-Gravenhage, 1990.

14. Wieringen J. C. van. Seculaire groeiverschuiving; lengte en gewicht surveys 1964-1966. in Nederland in Historisch Perspectief. Nederlands Instituut voor Praeventieve Geneeskunde TNO, Leiden, 1972.

15. Roede M. J. and Wieringen J. C. van Growth diagrams 1980. Netherlands third nation-wide survey. Tijdschr Soc. Gezondheidsz. 63, Suppl., 1-23, 1985.

16. Vliet R. C. J. A. van. Sociaal-Economische Gezondheidsverschillen bij Kinderen. Nederlands Economisch Instituut, Rotterdam, 1989.

17. Stolwijk A. M., Ocké M. C., Haar Romeny-Wachter C. C. ter et al. Sociaal-economische status, leefstijl en gezondheid in relatie tot lengte-naar-leeftijd bij 5-6 jarige kinderen. Tijdschr. Soc. Gezondheidsz. 68 $366-370,1990$.

18. Maas I. A. M., Poppel G. van, Bambang Oetomo S. et al. Antropometrie en sociaal-economische status bij 10-11 jarige jongens. Tijdschr. Soc. Gezondheidsz. 67, $179-182,1989$.

19. GG en GD Utrecht Verschillen in Gezondheidstoestand binnen de Stad Utrecht. GG en GD, Utrecht, 1987.

20. Deurenberg P., Hartog A. P. den, Linde A. van der and Westrate J. Secular changes in height, weight and body mass index of 18-19-year-old conscripts in the Netherlands. Tijdsch. Soc. Gezondheidsz. 66, 9-11, 1988 .

21. Uniken Venema H. P. and Hoogendijk J. Gezondheidsverschillen in Rotterdam. Een secundaire analyse van onderzoeksmateriaal. In Sociaal-Economische Gezondheidsverschillen Ond erzocht, Deel I: Reeks Sociaal-economische Gezondheidsverschillen no. (Edited by Mackenbach J. P.). Ministerie van Welzijn, Volksgezondheid en Cultuur, Rijswijk, 1990.

22. Halfens R., Drop M. J. and Philipsen H. Leefwijzen en Subjectieve Gezondheid van een Panel uit de Nederlandse Bevolking. Rijksuniversiteit Limburg, Maastricht, 1984.

23. Bos G. A. M. van den. Zorgen van en voor chronisch zieken [thesis] Bohn, Scheltema \& Holkema, Amsterdam, 1989.

24. Velden J. Van der. Unpublished data.

25. Ooijendijk W. T. M., Brekel E. J. G. van den, Stompedissel I., Ginneken J. K. S. van and Schaapveld K. Sociaal-economische status, gezondheid en medische consumptie. Unpublished manuscript.

26. Montfoort G. L. M., Galen W. C. C. van and Harris S. Ongevallen in Nederland. Onderzoek naar Prive -, Verkeers -, Sport - en Bedrijfsongevallen, aug '86aug '87. Stichting Consument en Veiligheid, Amsterdam, 1988.

27. Appels A., Otten F., Mendes de Leon C. et al. De KRIS follow-up studie VII. Sociaal-economische status en gezondheid. Tijdschr. Soc. Gezondheidsz. 68, 298-305, 1990.

28. Heederik D., Kromhout H., Burema J., Biersteker K. and Kromhout D. Occupational exposure and 25-year incidence rate of non-specific lung disease: The Zutphen Study. Int. J. Epidemiol. 19, 945-952, 1990.

29. Brouwer W. S. and Vrijhof B. J. Ziekteverzuim 1986-1987. Trends, Representativiteit, Verschillen Tussen Mannen en Vrouwen, Risikogroepen, Personeelsverloop. Stichting NIA, Amsterdam, 1989.

30. Bloemhoff A. and Winter C. R. de. De Invloed van Sociaal-Economische Status op Arbeidsongeschiktheid; een Longitudinale Analyse. Nederlands Instituut voor Praeventieve Gezondheidszorg TNO, Leiden, 1990.

31. Putten P. van der, Looman C. W. N., Maas P. J. van der et al. Medische bevindingen als risicofactoren voor een pathologisch einde van het arbeidsleven. Tijdschr. Soc. Gezondheidsz. 67, 22-27, 1989.

32. Bos T. van den, Lau-Ijzerman A., Habbema J. D. F. et al. Ongezondheid in de grote stad. I and II. Med. Contact 335-340 and 385-389, 1981.

33. Maas P. J. van der, Habbema J. D. F. and Bos G. A. $M$. van den. Vergelijkend Buurtonderzoek Amsterdam II: Sterfie en Ziekenhuisopnamen, 1977-1983. Instituut Maatschappelijke Gezondheidszorg, Erasmus Universiteit Rotterdam/Instituut Sociale Geneeskundle, Universiteit van Amsterdam, 1987.

34. Struben H. W. A. Sterfte in Den Haag (2) Over leeftijd en SES-niveau. Epidemiol. Bull. Grav. 23(3), 3-16, 1988.

35. Oers J. A. M. van and Teeuwen J. H. M. Sterfte en Sociaal-Economische Status in Rotterdam. GGDRotterdam, Rotterdam, 1990.

36. GG en GD Arnhem. Verschillen in Gezondheidstoestand tussen Stadsbuurten, p. 107. GG en GD, Arnhem, 1984.

37. Kunst A. E., Looman C. W. N. and Mackenbach J. P. Socio-economic mortality differences in the Netherlands in 1950-1984: a regional study of cause-specific mortality. Soc. Sci. Med. 31, 14l-152, 1990.

38. Wolff P. de and Meerdink J. Mortality rates in Amsterdam according to profession. In Proceedings of the World Pop Conf. 1954, Rome, 31 Aug, 10 Sept, 1954, Vol I, 51-61. United Nations, New York, 1954.

39. Schrama P. G. M. Bedrijfsgeneeskunde en volksgezondheid [thesis]. Van Gorcum, Assen, 1963.

40. Reek J. van and Zutphen W. M. van. Sterfte naar sociale klasse bij volwassenen in Nederland sinds de negentiende eeuw. Bevolking Gezin 2, 179-190, 1985.

41. Mares N. E. H. M., Aben D. J. M., Schouten E. G. et al. Inkomen en sterfte; resultaten van 25 jaar vervolgonderzoek bij mannelijke Amsterdamse ambtenaren. Ned. Tijdschr. Geneeskd. 132, 1109-1113, 1988.

42. Doornbos G. and Kromhout D. Educational level and mortality in a 32-year follow-up study of 18-yearold men in the Netherlands. Int. J. Epidemiol. 19 , 374-379, 1990.

43. Duijkers T. J., Kromhout D., Spruit I. P. et al. Inter-mediating risk factors in the relation between socio-economic status and 25-year mortality (the Zutphen Study). Int. J. Epidemiol. 18, 658-662, 1989. 
44. Doornbos J. P. R. and Nordbeck H. J. Perinatal Mortality; Obstetric Risk Factors in a Community of Mixed Ethnic Origin in Amsterdam. ICG Printing BV, Dordrecht, 1985.

45. Mackenbach J. $P$. and Leengoed $P$. L. $M$. van. Regionale verschillen in perinatale sterfte: het verband met enkele aspecten van de zorg rond de geboorte. Ned. Tijdschr. Geneeskd. 133, 1839-1843, 1989.

46. Haas-Posthuma J. H. de. Perinatale Sterfte in Nederland. Van Gorcum, Assen, 1962.

47. Haas-Posthuma J. H. de and Haas J. H. de. Infant loss in the Netherlands. Vital and Health Statistics Analytical Studies, NCHS Series 3, no. 11. Department of Health, Education and Welfare, Washington DC, 1968.

48. Stichting Volksgezondheid en Roken. Unpublished data.

49. Hulshof K. F. A. M., Löwik M. R. H., Wedel M., Aarnink E. J. M. and Brants H. A. M. Diet and Other Life-style Factors in Different Socio-economic Groups (Dutch Nutrition Surveillance System). TNO-CIVO Institutes, Zeist, 1990.

50. Centraal Bureau voor de Statistiek. De Leefsituatie van de Nederlandse Bevolking 1983, kernciffers. 's-Gravenhage, Staatsuitgeverij, 1984.

51. SCP Culturele Veranderingen. Unpublished data.

52. Reek J. van. Rookgedrag in Nederland van 1958-1982. Tijdschr. Alc. Drugs 9 (3), 99-103, 1983.

53. Hulshof K. F. A. M., Löwik M. R. H., Wedel M. Aarnink E. J. M., Kistemaker J. and Brants H. A. M. Clustering of Dietary Variables and Other Life-style Factors (Dutch Nutrition Surveillance System). TNOCIVO Institutes, Zeist, 1990.

54. Knibbe R. A., Drop M. J., Reek J. van et al. The development of alcohol consumption in the Netherlands: $1958-1981$. Br. J. Addict. 80, 411-419, 1985.

55. Kromhout D., Doornbos G. and Hoffmans M. D. A. F. Voedselkeuze, leeftwijze en sterfte in relatie tot opleiding. Tijdschr. Soc. Gezondheidsz. 66, 345-348, 1988.

56. Jonkers A. H., Lee A. P. M. van der and Bonjer F. H. Het COPIH-project 1971-1978. II Vergelijkingen van functiegroepen. Tijdschr. Soc. Geneeskd. 59, 540-544, 1981.

57. Seidell J. C., Bakx K. C., Deurenberg P. et al. The relation between overweight and subjective health according to age, social class, slimming behavior and smoking habits in Dutch adults. Am. J. Publ. Hlth 76, 1410-1415, 1986.

58. Baecke J. A. H., Buruma J., Frijters J. E. R. et al. Obesity in young Dutch adults: I, socio-demographic variables and body mass index. Int. J. Obes. 7, 1-12, 1983.

59. Raats G., Sanderman R. and Ormel J. Ongelijke Kansen op Geestelijke Gezondheid(szorg). Vakgroep Medische Sociologie Rijksuniversiteit Groningen, Groningen, 1987.

60. Swinkels H. W. A. M. Contacten van zuigelingen en kleuters met het consultatiebureau, 1981-1983. Mndber. Gezondh. (CBS) 7, 28-31, 1985.

61. Ridderbeek R. J. J, Bezoeken van zuigelingen en kleuters aan het consultatiebureau, 1985-1987. Mndber. Gezondh. (CBS) 5, 5-10, 1989.

62. König-Zahn C., Furer J. W., Tax B. et al. Een medische normering. Bepaling van de adequaatheid van het artsbezoek. Eindrapport 3 van het Regioproject Nijmegen. Instituut Sociale Geneeskunde, Nijmegen, 1987.

63. Tax B., Furer J. W. and König-Zahn C. Sociaaleconomisch milieu en gezondheidstoestand: een complexe relatie. Beschouwingen en analyses op basis van gegevens van het Regio project Nijmegen. In Sociaaleconomische Gezondheidsverschillen Onderzocht. Deel 1. Reeks Sociaal-economische Gezondheidsverschillen no. 4 (Edited by Mackenbach J. P.). Ministerie van Welzijn, Volksgezondheid en Cultuur, Rijswijk, 1990.

64. Velden J. van der. Unpublished data.

65. Brekel E. J. G. van den. Fysiotherapie in Nederland 1974-1983. Mndber. Gezondh. (CBS) 2, 5-16, 1985.

66. Janssen R. T. J. M., Doorslaer E. K. A. van and Thiemann E. De Verdeling van Lasten en Baten van Gezondheidszorg over Inkomensgroepen. Vakgroep Economie van de Gezondheidszorg Rijksuniversiteit Limburg, Maastricht, 1990.

67. Casparie A. F., Verhoeven S. and Ballegooie E. van. Sociaal-economische status en behandeling van diabetes mellitus type II. Tijdschr. Soc. Gezondheidsz. 68, 67-71, 1990.

68. Schröer C. A. P. and Bullinga R. Gezondheidsverschillen tussen Sociaal-Economische Statusgroepen: Effect van Verschillen in Leefwijze of Arbeidsbelasting? Vakgroep Medische Sociologie Rijksuniversiteit Limburg, Maastricht, 1990.

69. Ranchor A. V., Sanderman R. and Heuvel W. J. A. van den. An integrative approach to inequality in health: a longitudinal study encompassing SES, life-style, personality and health. Int. J. Hith Sci. 1, 121-135, 1990.

70. Leclerc A., Lert F. and Fabien C. Differential mortality: some comparisons between England and Wales, Finland and France, based on inequality measures. Int. J. Epidemiol. 19, 1001-1010, 1990.

71. Valkonen T. Adult mortality and level of education: a comparison of six countries. In Health Inequalities in European Countries (Edited by Fox J.), pp. 142-163. Gower, Aldershot, 1989.

72. Vågerö $\mathrm{D}$. and Lundberg $\mathrm{O}$. Health inequalities in Britain and Sweden. Lancet 2, 35-36, 1989.

73. Aiach P., Carr-Hill R., Curtis S. et al. Les Inégalités Sociales de Santé en France et en Grande Bretagne. INSERM, Paris, 1989.

74. Lahelma $E$. and Valkonen $T$, Health and social inequities in Finland and elsewhere. Soc. Sci. Med. 31, 257-265, 1990.

75. Blaxter M. A comparison of measures of inequality in morbidity. In Health Inequalities in European Countries (Edited by Fox J.), pp. 199-230. Gower, Aldershot, 1989.

76. Berkel-van Schaik A. B. van and Tax B. (rapporteurs) Naar een standaardoperationalisatie van SES. Reeks Sociaal-economische Gezondheidsverschillen no. 6. Ministerie van Welzijn, Volksgezondheid en Cultuur, Rijswijk, 1990. 